\title{
PROTOTYPE MONITORING AREA PARKIR MOBIL BERBASIS ARDUINO UNO UNTUK MENDETEKSI KETERSEDIAAN SLOT PARKIR SECARA OTOMATIS
}

\author{
Endang Sunandar ${ }^{1}$ \\ Asep Saefullah ${ }^{2}$ \\ Yudha Qirana Meka ${ }^{3}$ \\ Dosen Jurusan Sistem Komputer STMIK Raharja ${ }^{1}$, Dosen Jurusan Sistem Komputer STMIK Raharja ${ }^{2}$, \\ Alumni STMIK Raharja Jurusan Sistem Komputer ${ }^{3}$ \\ Email: endang.sunandar@raharja.info,asep.saefullah@raharja.info, yudha.qirana@ raharja.info
}

Diterima: 5 Desember 2016/ Disetujui : 19 Desember 2016

\begin{abstract}
Process monitoring conventional parking area is currently still using manual way to know the number and availability of existing capacity in the parking area, the monitoring process carried out in several ways such as recording the number of vehicles entering and see firsthand the state of the vehicle that was parked. The conventional method is certainly cause some problems for both the parking attendant and the owner of the vehicle, where these obstacles include the difficulty to obtain accurate information about the number of parking slots are available as well as difficult to know where to position the parking slot. Automatic parking monitoring system uses a microcontroller arduino uno as a data processor which utilizes multiple types of sensors are placed at some point areas, where the use of these sensors function as an input device that later processed with output an instruction to the servo motor and also the appearance of an information on an LCD screen that displays information about the number of parking slots are available as well as the location of the parking slot. In addition to using the LCD, the tool is also equipped with two indicator lights that show the status of the parking area and a buzzer will sound as a form of notification to the officer and the owner of the vehicle that the state of the car parking area has full.
\end{abstract}

Keywords : Parking Area, Arduino Uno, Sensor, LCD, Indicator

\begin{abstract}
ABSTRAK
Proses pemantauan area parkir yang konvensional saat ini masih menggunakan cara yang manual untuk mengetahui jumlah dan ketersediaan kapasitas yang ada di area parkir, proses pemantauan tersebut dilakukan dengan beberapa cara seperti mencatat jumlah kendaraan yang masuk serta melihat secara langsung keadaan dari kendaraan yang sedang parkir. Metode konvensional tersebut tentu menyebabkan beberapa kendala baik bagi petugas parkir maupun para pemilik kendaraan, dimana kendala tersebut antara lain sulitnya untuk mendapatkan informasi yang akurat mengenai jumlah slot parkir yang tersedia serta sulitnya untuk mengetahui dimana posisi slot parkir tersebut. Sistem pemantauan area parkir otomatis ini menggunakan mikrokontroler arduino uno sebagai pengolah data yang memanfaatkan beberapa jenis sensor yang diletakan di beberapa titik area, dimana penggunaan sensor tersebut berfungsi sebagai alat masukan yang kemudian diproses dengan hasil keluaran sebuah instruksi kepada motor servo dan juga tampilnya suatu informasi pada sebuah layar LCD yang menampilkan keterangan mengenai jumlah slot parkir yang tersedia serta lokasi dari slot parkir tersebut. Selain menggunakan LCD, alat ini juga dilengkapi dengan dua buah lampu indikator yang menunjukan status dari area parkir serta sebuah buzzer yang akan mengeluarkan suara sebagai bentuk pemberitahuan kepada petugas dan para pemilik kendaraan bahwa keadaan dari area parkir mobil tersebut telah terisi penuh.
\end{abstract}

Kata Kunci : Area Parkir, Arduino Uno, Sensor, LCD, Indikator. 


\section{PENDAHULUAN}

Pada era globalisasi saat ini perkembangan teknologi semakin berkembang pesat dan canggih, komputer sangat berperan dalam perkembangan teknologi ini karena dengan segala kelebihannya komputer telah menjadi bagian utama yang sangat diperlukan untuk membantu manusia dalam mengerjakan dan menyelesaikan berbagai tugas. Perkembangan komputer yang sangat pesat telah membawa banyak perubahan ke dalam berbagai aspek kehidupan karena pada dasarnya manusia sangat membutuhkan bantuan dari sesuatu yang dapat bekerja tepat, teliti dan juga tidak mengenal lelah. Sistem otomatisasi diketahui dapat menggantikan beberapa peran manusia dalam melaksanakan suatu kegiatan, seperti dalam hal pemantauan yang diharuskan mampu mengawasi keadaan sekitar dengan pengamatan yang lebih dari pada kemampuan panca indra manusia. Dengan didukungnya kemajuan teknologi dalam bidang elektronika dan komputer tentunya sistem otomatisasi akan mampu mengatasi berbagai permasalahan yang rumit sekalipun, dengan ketelitian dan kecepatan serta ketepatan yang sangat tinggi maka kedua bidang tersebut dapat menggantikan beberapa peran manusia dalam menyelesaikan permasalahan yang ada.

Proses pemantauan area parkir yang konvensional saat ini masih menggunakan cara yang manual untuk mengetahui jumlah dan ketersediaan kapasitas yang ada di area parkir, proses pemantauan tersebut antara lain dilakukan dengan beberapa cara seperti mencatat jumlah kendaraan yang masuk dan juga melihat secara langsung keadaan dari kendaraan yang sedang parkir. Metode konvensional ini tentu menyebabkan beberapa kendala baik bagi petugas parkir maupun bagi para pemilik kendaraan, dimana kendala tersebut antara lain sulitnya untuk mendapatkan informasi yang akurat mengenai jumlah slot parkir yang tersedia serta sulitnya untuk mengetahui dimana posisi slot parkir tersebut.

Dalam penelitian ini, peneliti menggunakan mikrokontroler arduino uno yang berfungsi sebagai pengontrol dan pemroses data sedangkan untuk parameter yang digunakan yaitu dengan menampilkan keterangan pada sebuah layar LCD yang mencakup jumlah kapasitas slot parkir yang tersedia, menunjukan posisi slot dan area parkir yang kosong serta memberikan indikator mengenai keadaan area parkir tersebut.

\section{PERMASALAHAN}

Di dalam suatu area khususnya yang memiliki batas kapasitas terkadang harus melibatkan beberapa orang untuk mengawasi area tersebut, dimana salah satu yang harus diperhatikan ialah mengenai jumlah kapasitas di dalam area tersebut apakah dapat terkendali dengan baik atau tidak. Seperti area parkir mobil, umumnya mereka yang ingin memarkirkan mobil langsung masuk ke dalam area parkir tersebut tanpa mengetahui terlebih dahulu apakah area parkir tersebut masih tersedia ruang untuk parkir atau tidak. Jika pada area parkir tersebut masih tersedia ruang untuk parkir maka hal tersebut bukanlah suatu masalah, tetapi bagaimana jika area parkir tersebut telah terisi penuh, tentunya hal tersebut akan membuat para pengendara mobil terpaksa untuk memutar balik kendaraan mereka dan mencari area parkir lain.

Dalam beberapa permasalahan yang di identifikasi pada latar belakang adapun penjelasan secara ringkas dari permasalahan yang ada, antara lain:

1. Bagaimana merancang dan membangun sebuah sistem yang mampu mendeteksi dan menghitung jumlah mobil yang berada di area parkir?

2. Bagaimana mengkomunikasikan mikrokontroler arduino uno dengan sensor yang digunakan untuk mendeteksi adanya mobil yang sedang parkir?

3. Bagaimana memanfaatkan sensor sebagai alat yang mampu mendeteksi adanya mobil yang akan melintasi palang pintu sehingga palang pintu yang berada di depannya dapat terbuka secara otomatis?

\section{METODE PENELITIAN}

Metode pengembangan sistem yang digunakan oleh penulis adalah model prototype jenis I. Prototype memberikan ide bagi pembuat maupun pemakai potensial tentang cara sistem akan berfungsi dalam bentuk lengkapnya. Adapun langkah-langkah pada model prototype jenis I sebagaimana yang dikemukakan oleh Raymond McLeod Jr. [6]: 


\section{Mengidentifikasi kebutuhan pemakai}

Analis sistem mewawancarai pemakai untuk mendapatkan gagasan dari apa yang diinginkan pemakai terhadap sistem.

\section{Mengembangkan prototype}

Analis sistem mungkin bekerja sama dengan spesialis informasi lain, menggunakan satu atau lebih peralatan prototype untuk mengembangkan sebuah prototype.

\section{Menentukan apakah prototype dapa diterima}

Analis mendidik pemakai dalam penggunaan prototype dan memberikan kesempatan kepada pemakai untuk membiasakan diri untuk menggunakan sistem dan tahap pengujian.

\section{Menggunakan prototype}

Prototype ini menjadi sistem yang dapat di operasionalkan dalam tahap implementasi sistem. Adapun untuk lebih mengetahui tahap implementasi sistem tersebut dapat dilihat pada gambar 1 di bawah ini.

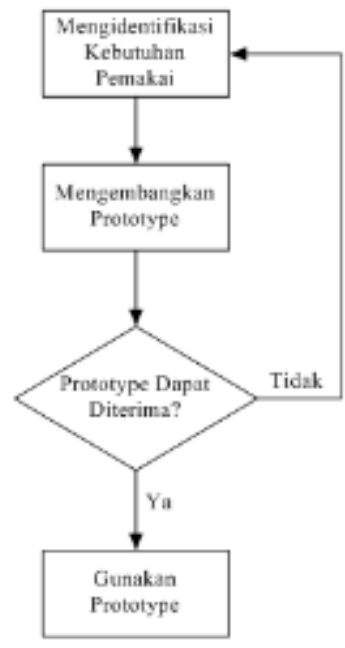

Gambar 1. Pengembangan Prototye Jenis 1

(Raymond McLeod Jr. (2001 : 151)

\section{LITERATURE REVIEW}

Dalam upaya mengumpulkan data perlu dilakukan studi pustaka sebagai salah satu dari penerapan metode penelitian yang akan dilakukan. Diantaranya metode tersebut adalah mengidentifikasikan kesenjangan (identify gaps), menghindari pembuatan ulang (reinventing the wheel), mengidentifikasikan metode yang pernah dilakukan, serta mengetahui orang lain yang spesialisasi dan area penelitian yang sama dibidang ini. Literature review adalah suatu survey literature mengenai penemuan-penemuan yang telah dilakukan oleh penelitian sebelumnya yang berhubungan dengan topik penelitian. Beberapa Literature Review tersebut antara lain:

1. Penelitian yang dilakukan oleh M. Hafiz Ilham yang berjudul "Perancangan Alat Penghitung Jumlah Orang Dalam Suatu Ruangan Dengan Menggunakan Sensor Infra Merah Berbasis Mikrokontroler AT89S52" pada tahun 2010. Penelitian ini membahas tentang bagaimana menghitung jumlah orang di dalam suatu ruangan secara otomatis dengan memanfaatkan sensor infrared sebagai alat masukan serta menggunakan seven segment sebagi alat keluaran yang 
menampilkan hasil penghitungan tersebut. Tidak hanya berfungsi sebagai alat penghitung, alat ini juga dipasangkan sebuah buzzer yang berfungsi sebagai alarm yang akan aktif pada saat adanya orang yang memasuki ruangan [5].

2. Penelitian yang dilakukan oleh Christoforus Yohannes yang berjudul "Sistem Penghitung Jumlah Barang Otomatis Dengan Sensor Ultrasonik" pada tahun 2011. Penelitian ini membahas tentang bagaimana merancang sebuah counter barang otomatis yang dapat menghitung jumlah barang serta mendeteksi adanya kerusakan pada barang, dimana counter barang tersebut memanfaatkan sebuah konveyor dengan motor DC sebagai penggerak konveyor dan juga memanfaatkan teknologi mikrokontroler, sensor infrared, photodioda, dan LCD. Pada saat barang terdeteksi maka sensor ultrasonik akan melakukan pengambilan data, dimana data yang didapatkan selanjutnya akan dikirim ke mikrokontroller dan hasil keluarannya ditampilkan melalui sebuah layar LCD. Adapun perangkat tambahan pada sistem ini berupa palang pemisah antara barang bagus dengan barang yang rusak dengan akurasi kebenaran yang mencapai $95-100 \%$ [2].

3. Penelitian yang dilakukan oleh Nasron yang berjudul "Aplikasi Counter Dengan Mikrokontroler Untuk Menghitung Penonton di Pintu Masuk Stadion Dengan Sensor Ping Dan LED” pada tahun 2011. Penelitian ini membahas tentang sebuah alat penghitung yang dapat dikendalikan menggunakan sensor ping sebagai sensor penghitung dan mikrokontroler AT89S52 yang digunakan untuk mengelola semua fungsi yang terkait dengan seluruh komponen. Alat ini dapat bekerja apabila sensor ping mendeteksi objek di depannya dengan jarak $3 \mathrm{~cm}$ sampai $3 \mathrm{~m}$ dengan batas kapasitas dalam menghitung jumlah sebanyak 10000 penonton. Dalam pembuatannya alat ini menggunakan dua buah LED, dimana LED hijau menyala menunjukan bahwa saklar dalam keadaan hidup dan alat tersebut akan segera mulai menghitung penonton yang melintasi pintu stadion secara satu persatu. Berbeda dengan LED hijau, LED merah menyala pada alat ini menunjukan bahwa jumlah penonton di stadion tersebut tekah memasuki batas maksimal sebanyak 10000 penonton [7].

4. Penelitian yang dilakukan oleh Bayu Dwi Rizkyadha Putra yang berjudul "Perancangan Counter Parkir Pada Pusat Perbelanjaan Berbasis Mikrokontroler ATmega 8535" pada tahun 2012. Penelitian ini membahas tentang pembuatan alat penghitung (counter) menggunakan sensor LDR (Light Dependent Resitor) dan mikrokontroler ATmega 8535 yang dibuat secara miniatur yang mampu menghitung atau mencacah pada saat sensor LDR tidak terkena cahaya sehingga alat tersebut mampu memberikan pemberitahuan kepada pengelola tempat parkir atau kepada pada pengendara mengenai jumlah kendaraan yang ada didalam gedung parkir tersebut [1].

5. Penelitian yang dilakukan oleh I Gusti Agung Putu Raka Agung dan I Made Irwan Susanto yang berjudul "Rancang Bangun Prototipe Penghitung Jumlah Orang Dalam Ruangan Terpadu Berbasis Mikrokontroler ATmega328P" pada tahun 2012. Penelitian ini membahas tentang sebuah sistem penghitung jumlah orang yang masuk dan keluar pada sebuah ruangan menggunakan sensor infrared dengan mikrokontroler ATMega 328P sebagai alat pengendali, dimana peralatan ini akan memadukan kehadiran atau jumlah orang dalam ruangan dengan hidup matinya lampu penerangan dan pengkondisi udara ruangan (AC) sehingga ruangan tetap layak digunakan dan pemakaian energinya bisa dikurangi. Adapun jumlah orang yang ada di dalam ruangan tesebut didapat dengan cara mengurangi jumlah orang yang masuk dengan jumlah orang yang ke luar dari ruangan tersebut dengan hasil yang ditampilkan pada sebuah layar LCD. Sistem yang dibuat tidak hanya sebagai alat penghitung tetapi juga dilengkapi rangkaian pengendali hidup matinya lampu penerangan di depan ruangan (di luar ruangan) dengan menggunakan RTC DS 1307, dengan pengendalian ini lampu penerangan dapat menyala otomatis pada sore hari dan mati saat pagi hari pada waktu yang sudah diset sebelumnya. Sedangkan untuk kemampuannya prototipe sistem yang dibuat sudah mampu menghitung jumlah orang yang berada dalam suatu ruangan dan mengatur hidup mati lampu penerangan dan pengkondisi udara ruangan tersebut [4].

6. Penelitian yang dilakukan oleh Dyah Siti Istiqomah yang berjudul "Prototipe Counter Kendaraan Diruang Parkir Berbasis Mikrokontroler AT89S51" pada tahun 2013. Penelitian ini membahas tentang alat penghitung jumlah kendaraan diruang parkir yang dirancang untuk menampilkan jumlah mobil yang sedang parkir serta jumlah parkiran yang masih tersedia (kosong) menggunakan seven segment, selain itu alat tersebut juga akan memberikan pertanda alarm dan informasi kata "PENUH" pada seven segment ketika kapasitas parkiran tersebut sudah mencapai jumlah maksimal. Alat penghitung kendaraan tersebut dirancang dengan menggunakan sensor 
LDR dan sumber cahaya yang memanfaatkan mikrokontroler AT89S51 sebagai pengolah data dan pengontrol perangkat keras lainnya dalam sistem penghitungan [3].

Dari beberapa sumber literature review diatas, dapat diketahui bahwa penelitian tentang pemanfaatan sensor DT-Sense IR Proximity Detector dan pembuatan sistem penghitung otomatis sudah banyak dibahas, meski demikian masih terdapat beberapa kekurangan pada masing-masing penelitian tersebut. Tujuan dilakukannya penelitian ini adalah untuk menutupi kekurangan umum yang ada pada penelitian sebelumnya, antara lain menunjukan keterangan mengenai posisi area parkir yang masih tersedia serta membuat palang pintu pada area parkir dapat terbuka dan tertutup secara otomatis pada saat adanya mobil yang akan melintas. Penelitin ini termasuk ke dalam jenis penelitian terapan karena berfokus untuk mencari solusi tentang masalah-masalah tertentu sehingga hasil dari penelitian ini bisa langsung diterapkan dan dapat dimanfaatkan untuk kepentingan bersama.

\section{PEMECAHAN MASALAH}

Tujuan dari penelitian ini adalah untuk membuat dan merancang sebuah prototype monitoring area parkir mobil berbasis arduino uno sebagai pemroses data masukan melalui beberapa sensor yang diletakan dibeberapa titik area, data masukan yang diperoleh tersebut selanjutnya akan diolah dalam sebuah bentuk penghitungan yang hasil keluarannya ditampilkan pada dua buah lampu indikator serta sebuah layar LCD yang menunjukan keterangan mengenai jumlah slot parkir yang tersedia serta lokasi dari slot parkir tersebut. Adapun untuk memudahkan dalam menganalisa alur kerja dari alat ini maka dipakailah sebuah diagram blok yang dapat dilihat pada gambar 2 di bawah ini.

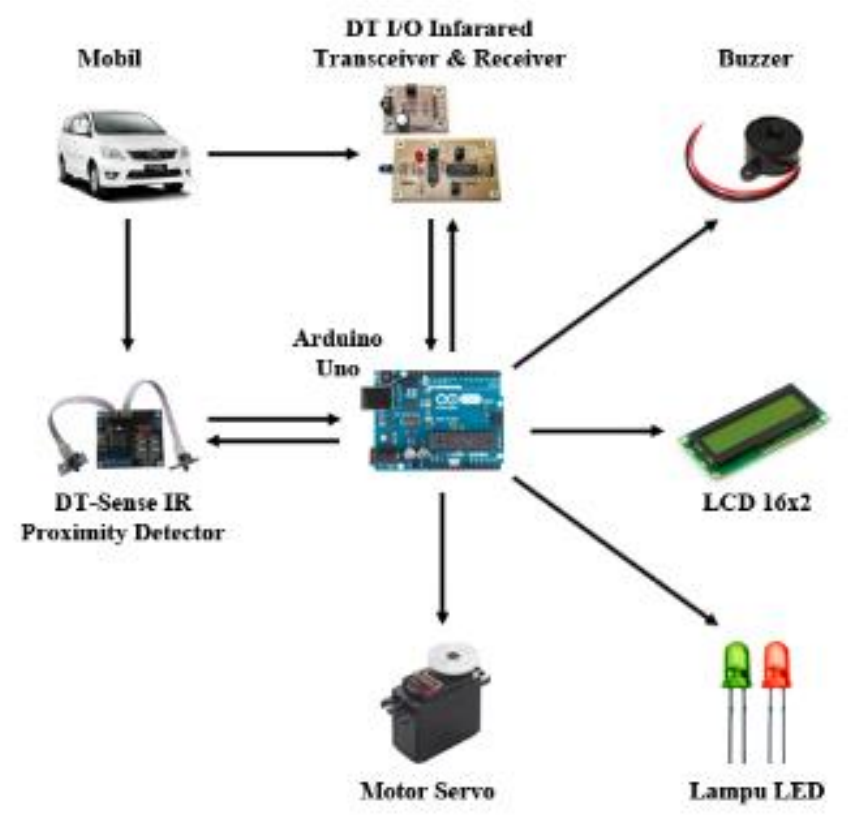

Gambar 2. Diagram Blok

Adapun keterangan mengenai gambar diatas antara lain : Untuk pemroses data alat ini menggunakan papan arduino uno dengan mikrokontroler berbasis ATmega328P. Untuk alat masukan pada alat ini menggunakan dua buah jenis sensor yang berbeda yaitu DT I/O Infrared Transceiver \& Receiver dan DT-Sense IR Proximity Detector, sedangkan untuk hasil keluaran yang diperoleh adalah berupa instruksi yang dikirim ke motor servo dan juga tampilnya suatu informasi pada layar LCD yang menampilkan keterangan mengenai jumlah slot parkir yang tersedia serta lokasi dari slot parkir tersebut. Selain menggunakan LCD alat ini juga dilengkapi dengan indikator lainnya seperti LED dan juga buzzer yang berfungsi sebagai media yang akan memberikan pemberitahuan mengenai status dari area parkir tersebut. 
Untuk mengetahui alur kerja dari diagram blok diatas adapun penjelasan sebagai berikut : Tanda panah pada gambar diatas adalah bentuk penjelasan mengenai proses dari alur kerja pada alat ini, dimana proses pertama pada alat ini ialah dimulai dengan DT I/O Infrared Transceiver \& Receiver yang berfungsi sebagai sensor yang mampu mendeteksi adanya mobil yang akan melintasi palang pintu pada area parkir tersebut, sensor jenis ini adalah modul sensor yang terdiri dari Infrared Transmitter sebagai modul pengirim data melalui gelombang infra merah dengan frekuensi carrier sebesar $38 \mathrm{kHz}$ dan Infrared Receiver adalah suatu modul penerima data melalui gelombang infra merah dengan frekuensi carrier sebesar $38 \mathrm{kHz}$. Untuk cara kerja dari sensor jenis ini adalah modul pengirim akan memancarkan gelombang inframerah kepada modul penerima, dimana data masukan dari sensor ini dapat diperoleh apabila pancaran dari gelombang inframerah tersebut tertutup atau terhalang oleh mobil yang akan melintasi palang pintu pada area parkir tersebut. Hasil dari data masukan tersebut selanjutnya akan diproses oleh arduino uno yang kemudian hasil keluaran berupa instruksi kepada motor servo untuk membuka palang pintu tersebut secara otomatis.

Proses kedua pada alat ini dimulai dari DT-Sense IR Proximity Detector, DT-Sense IR Proximity Detector adalah sebuah modul sensor cerdas yang dapat digunakan untuk mendeteksi jarak obyek dengan hasil keluaran berupa data digital yang menyatakan ada atau tidaknya obyek hingga jarak tertentu di depan sensor. Pada proses kedua ini DT-Sense IR Proximity Detector berfungsi sebagai modul sensor yang akan menerima data masukan pada saat adanya mobil yang parkir tepat berada didepannya, hasil dari data masukan yang diperoleh tersebut selanjutnya akan diproses oleh arduino uno dalam bentuk penghitungan jumlah slot parkir yang tersisa dengan hasil keluaran yang akan ditampilkan oleh sebuah layar LCD 16x2 yang mancakup dua keterangan mengenai jumlah slot parkir yang tersedia serta lokasi dari slot parkir tersebut. Tidak hanya menggunakan LCD 16x2, alat ini juga dilengkapi dengan hasil keluaran lainnya yaitu adanya dua buah lampu LED dengan warna yang berbeda (merah dan hijau), LED tersebut akan menyala bersamaan dengan LCD 16x2 dimana lampu LED yang menyala pada alat ini berfungsi sebagai indikator yang menunjukan status dari area parkir tersebut. Adapun keterangan LED hijau yang menyala menunjukan keterangan bahwa masih adanya slot parkir mobil yang tersedia, sedangkan apabila LED merah yang menyala maka status tersebut menunjukan bahwa area parkir mobil tersebut telah terisi penuh. Khusus untuk LED berwarna merah akan menyala bersamaan dengan sebuah buzzer yang akan mengeluarkan suara selama beberapa detik apabila status dari area parkir telah terisi penuh.

\section{Flowchart Sistem}

Dalam pembuatan sistem ini terdapat dua flowchart yang menjelaskan alur ataupun langkahlangkah dari sistem yang dibuat. Adapun kedua flowchart sistem tersebut antara lain:

\section{Flowchart Sistem Mobil Masuk}

Flowchart sistem mobil masuk adalah sebuah alur dari cara kerja alat yang menjelaskan tentang bagaimana kondisi awal mobil yang akan parkir hingga mobil tersebut selesai parkir. Adapun untuk lebih mengetahui bagaimana alur dari mobil yang akan memasuki area parkir dapat dilihat pada gambar 3 di bawah ini. 


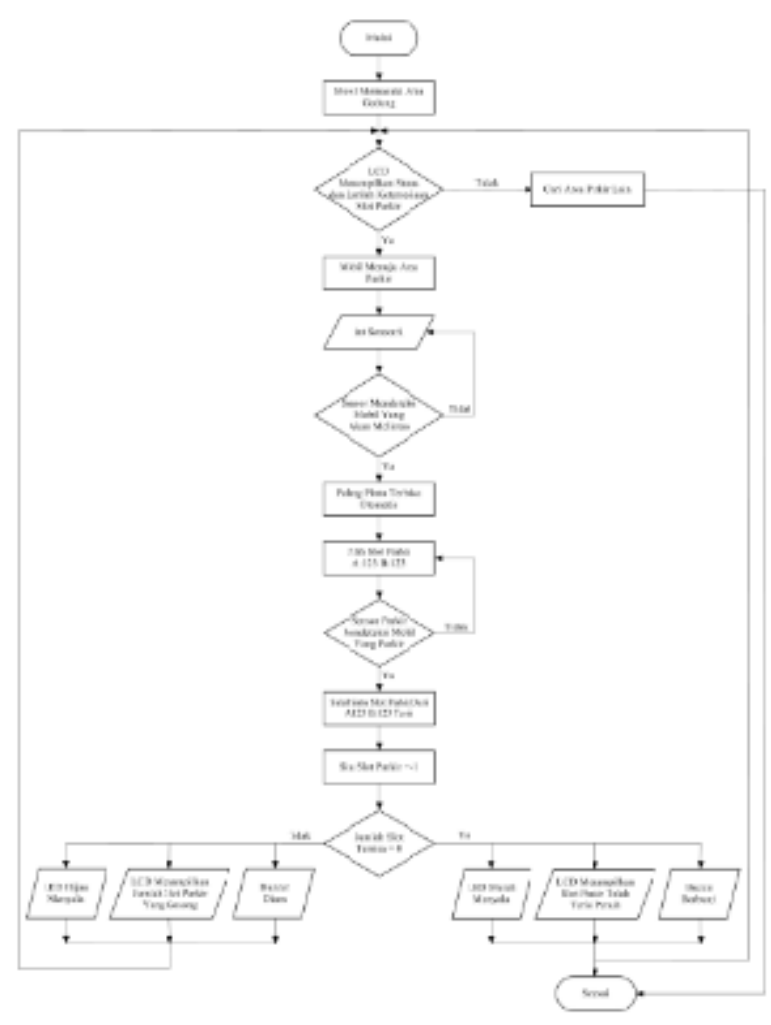

Gambar 3. Diagram Flowchart Mobil Masuk

Langkah awal dari proses ini dimulai dari sebuah mobil yang baru memasuki area gedung dan pada saat yang bersamaan pengendara tersebut akan melihat sebuah layar LCD yang berada di area depan, LCD tersebut adalah sebuah layar yang memberikan informasi mengenai status ataupun keadaan dari area parkir. Apabila kondisi pada layar LCD menunjukan bahwa slot parkir pada area tersebut telah terisi penuh maka pengendara tersebut harus memarkirkan mobilnya pada area parkir lain, namun apabila kondisi pada layar LCD menunjukan bahwa masih tersedianya slot parkir maka pengendara tersebut dapat memarkirkan mobilnya pada area tersebut. Informasi yang ditampilkan pada layar LCD tidak hanya berupa jumlah slot parkir yang tersedia saja tetapi juga LCD tersebut menampilkan lokasi dari slot parkir yang masih kosong sehingga pengendara tersebut dapat dengan mudah mengetahui lokasi dari slot parkir tersebut. Setelah pengendara tersebut memastikan bahwa masih adanya slot parkir yang tersedia melalui informasi yang ditampilkan oleh layar LCD maka langkah selanjutnya pengendara tersebut menuju area tersebut, namun pada saat menuju area parkir tersebut pengendara akan terhalang oleh sebuah palang pintu yang menutupi lajunya mobil untuk menuju ke arah area parkir, namun pada keadaan tersebut pengendara tidak perlu mencari atau memanggil petugas yang berada dipos belakang untuk membukanya karena pada lokasi tersebut sudah terdapat sebuah sensor yang diletakan diantara palang pintu sehingga pada saat adanya mobil yang akan melintas maka secara otomatis sensor tersebut pun akan mendeteksi dan mengirimkan instruksi kepada motor servo untuk membuka palang pintu tersebut secara otomatis, dan pada saat palang pintu terbuka dan mobil telah melintasinya maka dengan sendirinya palang pintu tersebut pun akan tertutup.

Setelah melewati palang pintu maka langkah selanjutnya pengedara mobil akan memilih slot parkir yang akan dijadikannya lokasi untuk memarkirkan kendaraannya (pada simulasi ini penulis membuat sebuah area parkir dengan jumlah slot parkir sebanyak 6 buah, dimana ke 6 slot tersebut dikelompokan menjadi 2 area yaitu : Area A dan Area B dengan pengertian pada setiap area memiliki 3 buah slot parkir). parkir). Setelah pengendara telah mengetahui terlebih dahulu lokasi slot parkir yang kosong melalui sebuah layar LCD yang berada di depan maka langkah selanjutnya pengedara tersebut menuju dan memarkirkan mobilnya di slot tersebut, dimana pada 
keadaan ini disimulasikan bahwa pengendara tersebut memarkirkan mobilnya pada slot parkir yang berada di Area A1. Pada saat pengendara tersebut memarkirkan mobilnya maka secara otomatis mobil tersebut pun akan terdeteksi oleh sebuah sensor yang berada di slot tersebut karena pada dasarnya alat ini menggunakan sebuah sensor pendeteksi yang diletakan pada setiap slot parkir yang ada sehingga dengan penggunaan sensor tersebut akan menjadikan lokasi dari slot parkir tersebut dapat diketahui lokasinya, dan pada saar mobil tersebut parkir maka secara otomatis sensor tersebut akan mengirim sebuah data masukan kepada arduino uno dan mengirim hasil keluarannya ke sebuah layar LCD dengan cara menampilkan bahwa slot pada Area A1 telah terisi serta memperbarui jumlah slot parkir yang tersedia dikurangi sebanyak -1 dari jumlah yang ditampilkan sebelumnya. Langkah-langkah tersebut akan akan terus berulang apabila masih adanya slot parkir yang tersedia, dimana keadaan masih tersedianya slot tersebut tidak hanya ditampilkan melalui sebuah layar LCD saja tetapi juga akan di tampilkan oleh indikator lainnya yaitu sebuah lampu LED berwarna hijau yang berada dipos depan dengan keterangan yang menunjukan bahwa masih adanya slot yang tersedia.

Langkah-langkah tersebut hanya akan berhenti atau selesai apabila slot-slot yang berada di area parkir tersebut telah terisi penuh semua atau menunjukan bahwa slot yang tersedia sebanyak 0, dimana pada saat itu juga LCD akan menampilkan sebuah teks yang menunjukan bahwa slot dari area parkir telah terisi penuh yang disertai indikator lain yaitu menyalanya sebuah lampu LED berwarna merah dan juga sebuah buzzer yang akan mengeluarkan suara sebagai suatu pemberitahuan kepada para pengendara yang baru datang untuk memarkirkan mobilnya di area parkir lain.

\section{Flowchart Sistem Mobil Keluar}

Flowchart sistem mobil keluar adalah sebuah alur dari cara kerja alat yang menjelaskan tentang bagaimana kondisi awal mobil yang sedang parkir hingga mobil tersebut keluar dari area gedung. Adapun untuk lebih mengetahui bagaimana alur dari mobil yang akan keluar dari area parkir dapat dilihat pada gambar 4 di bawah ini.

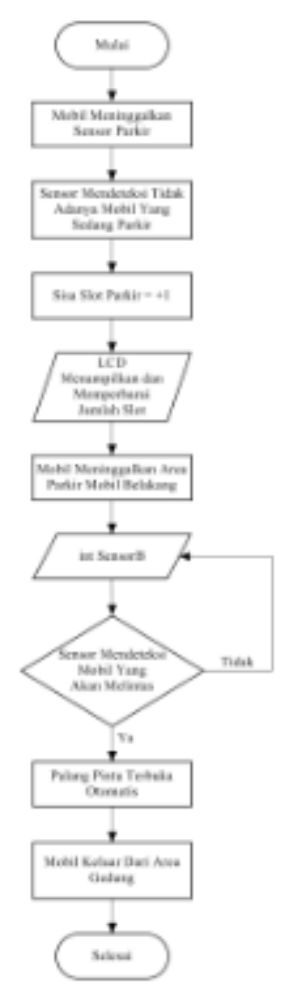

Gambar 4. Diagram Flowchart Mobil Keluar 
Berbeda dengan flowchart sistem sebelumnya yang membahas tentang bagaimana proses sebuah mobil menuju area parkir, flowchart sistem ini akan melanjutkan alur tersebut namun dengan penjelasan yang berbeda yaitu bagaimana mobil tersebut dapat keluar dari area parkir yang selanjutnya meninggalkan area gedung.

Langkah awal dari proses ini dimulai dari sebuah mobil yang sedang parkir di slot A1 akan meninggalkan slot parkir tersebut, pada saat mobil tersebut meninggalkan slot parkir maka secara otomatis mobil tersebut akan menjauh dan meninggal sensor yang berada di slot A1 sehingga pada kondisi saat itu sensor yang berada di slot A1 tidak lagi mendeteksi bahwa masih adanya mobil yang sedang parkir. Hasil masukan tersebut selanjutkan dikirim ke arduino uno yang kemudian diproses dengan cara memperbarui dan menambahkan jumlah slot parkir yang tersedia sebanyak +1 dari jumlah yang ditampilkan sebelumnya, sehingga pada layar LCD yang berada dipos depan akan menampilkan keterangan bahwa slot parkir pada A1 tersebut statusnya berubah dari yang sebelumnya terisi menjadi status slot parkir tersedia atau kosong. Tidak hanya itu, pada kondisi tersebut apabila sebelumnya keadaan area parkir telah terisi penuh dan adanya sebuah mobil yang akan keluar dari area parkir tersebut maka secara otomatis dan disaat yang bersamaan lampu indikator yang sebelumnya menyala berwarna merah akan berubah menjadi lampu indikator berwarna hijau yang menunjukan bahwa slot parkir pada area parkir tersebut masih ada yang kosong atau tersedia.

Kembali ke proses sebelumnya, pada saat mobil telah meninggalkan area parkir maka laju dari mobil tersebut akan terhalang oleh sebuah palang pintu namun pada kondisi ini sama halnya dengan proses pada mobil tersebut memasuki area parkir, dimana pengendara tidak harus mencari dan meminta petugas untuk membuka palang pintu tersebut karena nantinya palang tersebut akan terbuka secara otomatis dengan adanya sebuah sensor yang terpasang diantara motor servo. Pada saat mobil tersebut akan melintasi palang pintu maka disaat bersamaan sensor tersebut akan mendeteksi dan menerima data masukan yang kemudian diproses dan hasil keluarannya dalam bentuk instruksi kepada motor servo untuk membuka palang pintu tersebut secara otomatis dan pada saat mobil tersebut telah melintasi palang pintu maka dengan sendirinya palang pintu tersebut pun akan tertutup dan pada akhirnya pengendara mobil pun dapat keluar dari area gedung.

Proses pada flowchart sistem ini akan berulang secara terus menerus, adapun yang membedakannya terdapat pada lokasi dari slot parkir tersebut karena bagaimanapun pada dasarnya setiap slot parkir pada alat ini memiliki variabel khusus dalam artian setiap slot parkir berada di area dan slot parkir yang berbeda satu dengan yang lainnya.

\section{Rancangan Pendeteksi Area Parkir Otomatis}

Rancangan dari monitoring area parkir mobil ini dibuat dalam bentuk prototype yang menyerupai bentuk asli dari area parkir yang ada sehingga sistem yang dirancang dapat berjalan dengan baik. Adapun untuk lebih mengetahui bagaimana rancangan dari bentuk prototype tersebut dapat dilihat pada gambar 5 di bawah ini. 


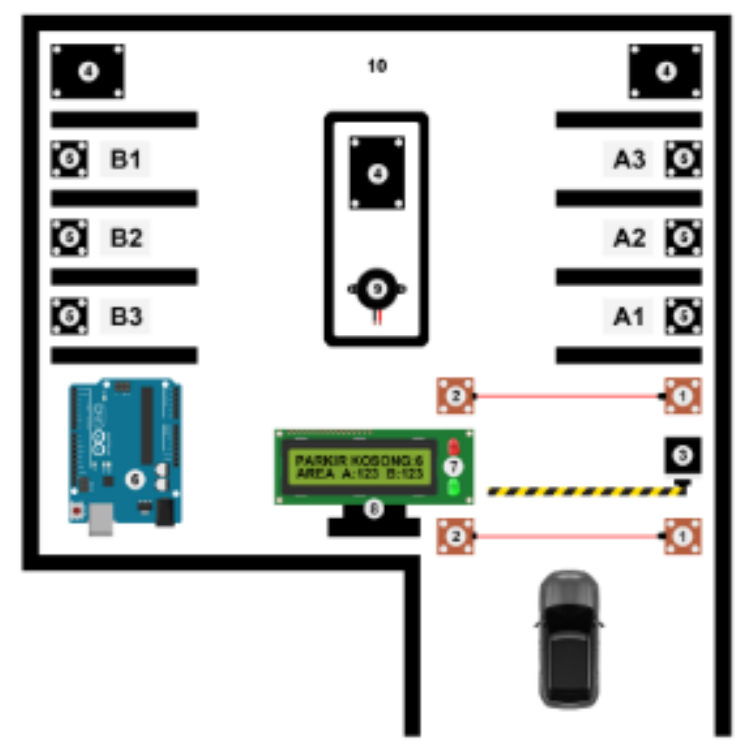

Gambar 5. Rancangan Prototype Monitoring Area Parkir Mobil

Agar lebih mudah dalam mengetahui keterangan dari rancangan prototype di atas maka adapun penjelasan yang dapat dilihat pada tabel 1 di bawah ini.

Tabel 1. Keterangan Desain Prototype

\begin{tabular}{|c|c|c|}
\hline No. & Nama & Keterangan \\
\hline 1. & $\begin{array}{l}\text { Modul Infrared } \\
\text { Transmitter }\end{array}$ & $\begin{array}{l}\text { Sebuah modul pengirim data melalui gelombang infra merah dengan } \\
\text { frekuensi carrier sebesar } 38 \mathrm{kHz} \text { yang digunakan sebagai sensor yang } \\
\text { mampu mendeteksi adanya mobil yang akan melintasi palang pintu pada area } \\
\text { parkir. }\end{array}$ \\
\hline 2. & $\begin{array}{l}\text { Modul Infrared } \\
\text { Receiver }\end{array}$ & $\begin{array}{l}\text { Sebuah modul penerima data melalui gelombang infra merah dengan } \\
\text { frekuensi carrier sebesar } 38 \mathrm{kHz} \text { yang digunakan sebagai sensor yang } \\
\text { mampu mendeteksi adanya mobil yang akan melintasi palang pintu pada area } \\
\text { parkir. }\end{array}$ \\
\hline 3. & Motor Servo & $\begin{array}{l}\text { Sebuah motor penggerak yang digunakan sebagai alat penggerak palang } \\
\text { pintu pada area parkir yang dapat terbuka dan tertutup secara otomatis. }\end{array}$ \\
\hline 4. & $\begin{array}{l}\text { Modul Infared } \\
\text { Proximity } \\
\text { Detector }\end{array}$ & $\begin{array}{l}3 \text { buah sensor detektor yang disetiap modulnya mempunyai } 2 \text { buah modul } \\
\text { sensor IR yang dapat bekerja secara mandiri dan simultan. }\end{array}$ \\
\hline 5. & $\begin{array}{l}\text { Modul Sensor } \\
\text { Infrared }\end{array}$ & $\begin{array}{l}6 \text { buah sensor pendeteksi yang digunakan sebagai sensor penghitung jumlah } \\
\text { mobil yang sedang parkir. Dalam rancangan prototype ini posisi mobil yang } \\
\text { parkir membelakangi sensor. }\end{array}$ \\
\hline 6. & Arduino Uno & $\begin{array}{l}\text { Sebuah papan mikrokontroler berbasis ATmega } 328 \text { yang berfungsi sebagai } \\
\text { pemroses data berdasarkan perintah yang diberikan oleh sensor. }\end{array}$ \\
\hline 7. & LED & $\begin{array}{l}\text { Dua buah lampu yang berfungsi sebagai indikator yang menunjukan status } \\
\text { dari area parkir (hijau = masih adanya slot parkir yang tersedia, merah }=\text { slot }\end{array}$ \\
\hline
\end{tabular}




\begin{tabular}{|c|l|l|}
\hline & & parkir telah terisi penuh). \\
\hline 8. & LCD 16x2 & $\begin{array}{l}\text { Sebuah layar yang memberikan keterangan mengenai jumlah ketersediaan } \\
\text { slot parkir yang ada. }\end{array}$ \\
\hline 9. & Buzzer & $\begin{array}{l}\text { Sebuah indikator yang mengeluarkan suara pada saat status dari area parkir } \\
\text { belakang telah terisi penuh. }\end{array}$ \\
\hline 10. & Area Prototype & $\begin{array}{l}\text { Sebuah area parkir yang terbuat dari papan akrilik, desain tersebut dibuat } \\
\text { sedemikian rupa membentuk area parkir yang asli dengan cara memisahkan } \\
\text { setiap kendaraan yang parkir dengan garis pembatas serta tertera nomor } \\
\text { disetiap barisnya. Pada rancangan prototype ini dibuat simulasi dengan } \\
\text { jumlah slot parkir yang ada sebanyak 6 buah yang terbagi menjadi 2, yaitu } \\
\text { area A dan area B. }\end{array}$ \\
\hline
\end{tabular}

\section{Penulisan Program Pada Mikrokontroler}

Untuk memasukkan program kedalam sebuah mikrokontroler ATmega328P dibutuhkan Driver USB, IDE Arduino 1.0.5 dan Ardunio Uno Board agar program yang dibuat dapat berjalan di dalam mikrokontroler. Instalasi driver untuk Arduino Uno dengan Windows 7, Vista atau XP. Hubungkan board dan tunggu windows untuk memulai proses instalasi driver. Pada bagian Ports (COM \& LPT) akan tampak sebuah port terbuka dengan nama Arduino Uno (COMxx), selanjutnya update driver software dan ambil file driver uno, dengan nama ArduinoUNO.inf. Adapun untuk memasukkan program ke dalam mikrokontroler melalui menu Upload dapat dilihat pada gambar 6 di bawah ini.

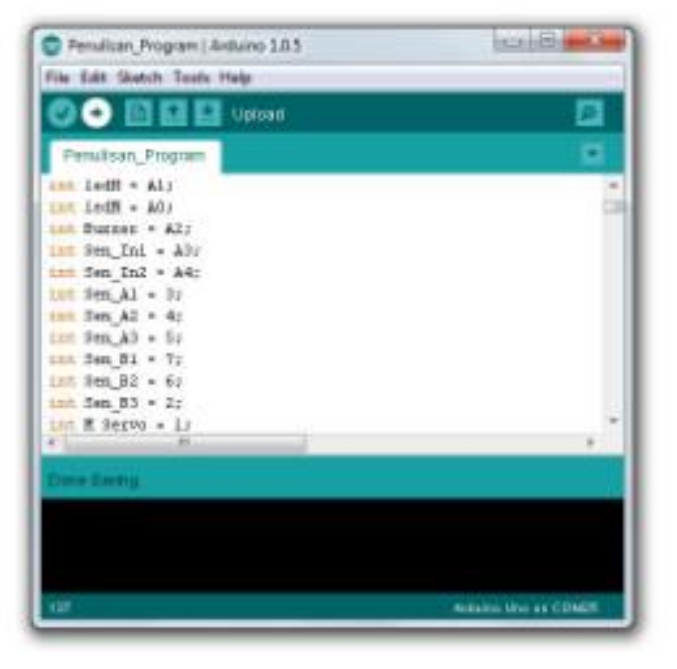

Gambar 6. Penulisan dan Upload Program

\section{UJI COBA DAN IMPLEMENTASI}

\section{Uji Coba}

Setelah melakukan berbagai tahapan perancangan, maka langkah selanjutnya adalah melakukan serangkaian uji coba pada masing - masing blok rangkaian yang bertujuan untuk mendapatkan hasil sesuai rancangan. Tujuan dari pengujian ini adalah melihat proses komukasi antara sensor, arduino uno, motor servo, lcd dan indikator LED. Hasil pengujian dilakukan dengan menggunakan metode black box yang dapat dilihat pada tabel 2 dan tabel 3 di bawah ini. 
Tabel 2. Pengujian Black Box Pada Sensor

\begin{tabular}{|c|c|c|c|}
\hline No. & Nama Form & Kondisi Pengujian & Hasil Pengujian \\
\hline \multirow{3}{*}{1.} & \multirow{3}{*}{$\begin{array}{l}\text { DT I/O Infrared } \\
\text { Transceiver \& } \\
\text { Receiver }\end{array}$} & $\begin{array}{l}\text { Meletakan sebuah mobil di depan } \\
\text { pancaran sensor infrared. }\end{array}$ & $\begin{array}{l}\text { Motor servo terbuka secara } \\
\text { otomatis. }\end{array}$ \\
\hline & & $\begin{array}{l}\text { Menjauhkan sebuah mobil yang ada } \\
\text { di depan pancaran sensor infrared. }\end{array}$ & $\begin{array}{l}\text { Motor servo tertutup secara } \\
\text { otomatis. }\end{array}$ \\
\hline & & $\begin{array}{l}\text { Meletakan dan menjaukan sebuah } \\
\text { mobil tepat di depan pancaran } \\
\text { sensor infrared dalam keadaan } \\
\text { cahaya gelap. }\end{array}$ & $\begin{array}{l}\text { Tetap dapat melakukan input dan } \\
\text { mengirimkan instruksi kepada } \\
\text { motor servo (tidak ada pengaruh } \\
\text { cahaya). }\end{array}$ \\
\hline \multirow{3}{*}{2.} & \multirow{3}{*}{$\begin{array}{l}\text { DT-Sense IR } \\
\text { Proximity } \\
\text { Detector }\end{array}$} & $\begin{array}{l}\text { Meletakan sebuah mobil tepat di } \\
\text { depan pancaran modul sensor } \\
\text { infrared. }\end{array}$ & $\begin{array}{l}\text { Melakukan proses penghitungan } \\
\text { dengan mengurangi sisa slot } \\
\text { sebelumnya sebanyak }-1 \text {. }\end{array}$ \\
\hline & & $\begin{array}{l}\text { Menjauhkan sebuah mobil yang ada } \\
\text { di depan pancaran modul sensor } \\
\text { infrared. }\end{array}$ & $\begin{array}{l}\text { Melakukan proses penghitungan } \\
\text { dengan menambahkan sisa slot } \\
\text { sebelumnya sebanyak }+1 \text {. }\end{array}$ \\
\hline & & $\begin{array}{l}\text { Meletakan dan menjaukan sebuah } \\
\text { mobil tepat di depan pancaran } \\
\text { modul sensor infrared dalam } \\
\text { keadaan cahaya gelap. }\end{array}$ & $\begin{array}{l}\text { Tetap dapat melakukan proses } \\
\text { penghitungan (tidak ada pengaruh } \\
\text { cahaya) }\end{array}$ \\
\hline
\end{tabular}

Tabel 3. Pengujian Black Box Pada Hasil Keluaran

\begin{tabular}{|c|l|l|l|c|}
\hline No. & \multicolumn{1}{|c|}{$\begin{array}{c}\text { Nama } \\
\text { Pengujian }\end{array}$} & \multicolumn{1}{|c|}{ Test Input } & \multicolumn{1}{|c|}{ Hasil Yang Diharapkan } & $\begin{array}{c}\text { Hasil } \\
\text { Pengujian }\end{array}$ \\
\hline \multirow{2}{*}{1.} & $\begin{array}{l}\text { Tampilan } \\
\text { LCD }\end{array}$ & $\begin{array}{l}\text { DT-Sense Infrared Proximity } \\
\text { Detector } \text { mendeteksi adanya } \\
\text { objek sebanyak 1-5. }\end{array}$ & $\begin{array}{l}\text { LCD akan menampilkan jumlah } \\
\text { slot parkir yang kosong serta } \\
\text { menunjukan dimana letak posisi } \\
\text { slot parkir tersebut. }\end{array}$ & $\begin{array}{c}\text { Sesuai } \\
\text { Harapan }\end{array}$ \\
\cline { 3 - 5 } & $\begin{array}{l}\text { DT-Sense Infrared Proximity } \\
\text { Detector } \text { mendeteksi adanya } \\
\text { objek sebanyak 6. }\end{array}$ & $\begin{array}{l}\text { LCD akan menampilkan sebuah } \\
\text { teks yang bertuliskan "Parkir } \\
\text { Penuh". }\end{array}$ & $\begin{array}{c}\text { Sesuai } \\
\text { Harapan }\end{array}$ \\
\hline \multirow{2}{*}{2.} & $\begin{array}{l}\text { Indikator } \\
\text { LED }\end{array}$ & $\begin{array}{l}\text { Jumlah mobil yang } \\
\text { terdeteksi oleh DT-Sense } \\
\text { Infrared Proximity Detector } \\
\text { <5. }\end{array}$ & $\begin{array}{l}\text { Lampu LED berwarna hijau } \\
\text { menyala. }\end{array}$ & $\begin{array}{c}\text { Sesuai } \\
\text { Harapan }\end{array}$ \\
\cline { 3 - 5 } & $\begin{array}{l}\text { Jumlah mobil yang } \\
\text { terdeteksi oleh DT-Sense }\end{array}$ & $\begin{array}{l}\text { Lampu LED berwarna Merah } \\
\text { menyala. }\end{array}$ & $\begin{array}{c}\text { Sesuai } \\
\text { Harapan }\end{array}$ \\
\hline
\end{tabular}




\begin{tabular}{|c|c|c|c|c|}
\hline & & $=6$. & & \\
\hline \multirow{4}{*}{3} & \multirow{4}{*}{ Buzzer } & $\begin{array}{l}\text { Jumlah mobil yang } \\
\text { terdeteksi oleh DT-Sense } \\
\text { Infrared Proximity Detector } \\
<5 \text {. }\end{array}$ & Buzzer diam atau tidak berbunyi. & $\begin{array}{c}\text { Sesuai } \\
\text { Harapan }\end{array}$ \\
\hline & & $\begin{array}{l}\text { Jumlah mobil yang } \\
\text { terdeteksi oleh DT-Sense } \\
\text { Infrared Proximity Detector } \\
=6 .\end{array}$ & $\begin{array}{l}\text { Buzzer akan berbunyi selama } \\
\text { beberapa detik. }\end{array}$ & $\begin{array}{c}\text { Sesuai } \\
\text { Harapan }\end{array}$ \\
\hline & & $\begin{array}{l}\text { Meletakan sebuah mobil } \\
\text { tepat di depan pancaran } \\
\text { modul DT-Sense IR } \\
\text { Proximity Detector. }\end{array}$ & $\begin{array}{l}\text { Buzzer akan berbunyi beep } \\
\text { selama } 1 \mathrm{x} .\end{array}$ & $\begin{array}{c}\text { Sesuai } \\
\text { Harapan }\end{array}$ \\
\hline & & $\begin{array}{l}\text { Menjauhkan sebuah mobil } \\
\text { yang ada di depan pancaran } \\
\text { modul DT-Sense IR } \\
\text { Proximity Detector }\end{array}$ & Buzzer diam atau tidak berbunyi. & $\begin{array}{c}\text { Sesuai } \\
\text { Harapan }\end{array}$ \\
\hline \multirow{2}{*}{4.} & \multirow{2}{*}{$\begin{array}{l}\text { Motor } \\
\text { Servo }\end{array}$} & $\begin{array}{l}\text { Mobil hanya melewati } 1 D T \\
\text { I/O Infrared Transceiver \& } \\
\text { Receiver }\end{array}$ & $\begin{array}{l}\text { Motor servo terbuka namun } \\
\text { setelah itu tidak dapat tertutup. }\end{array}$ & $\begin{array}{c}\text { Sesuai } \\
\text { Harapan }\end{array}$ \\
\hline & & $\begin{array}{l}\text { Mobil melewati kedua } D T \\
\text { I/O Infrared Transceiver \& } \\
\text { Receiver }\end{array}$ & $\begin{array}{l}\text { Motor servo terbuka dan } \\
\text { kemudian tertutup secara } \\
\text { otomatis }\end{array}$ & $\begin{array}{c}\text { Sesuai } \\
\text { Harapan }\end{array}$ \\
\hline
\end{tabular}

Hasil keluaran dari alat ini akan ditampilkan pada sebuah layar LCD 16x2 yang menampilkan keterangan mengenai jumlah slot parkir yang tersedia serta lokasi dari slot parkir tersebut. Prototype monitoring area parkir mobil ini tidak hanya menggunakan LCD saja tetapi juga dilengkapi dengan sebuah LED berwarna hijau dan merah sebagai indikator yang menunjukan status dari area parkir. Adapun tampilan dari hasil keluaran LCD dan LED tesebut dapat dilihat pada gambar 7 dan gambar 8 di bawah ini.

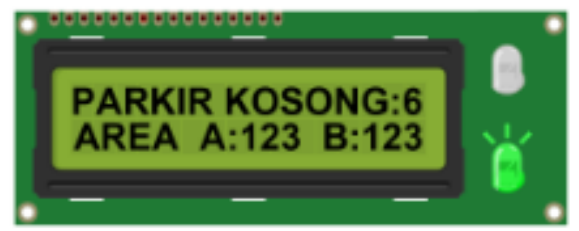

Gambar 7. Hasil Keluaran LCD dan Indikator LED (Area Parkir Kosong)

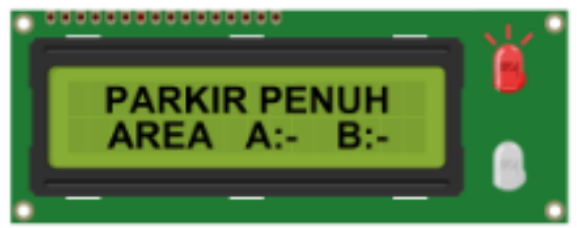

Gambar 8. Hasil Keluaran LCD dan Indikator LED (Area Parkir Penuh) 
Pada kedua hasil keluaran yang ditampilkan oleh LCD dan LED diatas menunjukan keterangan sebagai berikut:

a. LCD Baris Pertama : Menampilkan jumlah slot parkir yang masih tersedia atau kosong.

b. LCD Baris Kedua : Menampilkan lokasi area parkir yang masih tersedia atau kosong.

c. LED Merah : Menunjukan status area parkir telah terisi penuh.

d. LED Hijau : Menunjukan status masih adanya slot parkir yang tersedia atau kosong.

\section{Implementasi}

Setelah melakukan uji coba alat dengan hasil sesuai dengan rancangan maka langkah selanjutnya adalah implementasi alat. Adapun kebutuhan aplikasi dari sistem yang akan diimplementasikan antara lain:

\section{Kebutuhan Aplikasi :}

a. 1 buah Arduino Uno R3 : Sebagai Platform untuk memasukkan program dan mengolah data pada mikrokontroler ATmega 328.

b. 1 buah Motor Servo standard : Sebagai motor yang menggerakan palang pintu pada area parkir secara otomatis.

c. 2 buah Sensor DT I/O Infrared Transceiver \& Receiver : Sebagai pendeteksi mobil yang ingin memasuki ataupun keluar dari area parkir, mobil yang terdeteksi bertindak sebagai data masukan yang akan memberikan perintah kepada motor penggerak untuk membuka dan menutup palang pintu secara otomatis.

d. 3 buah Modul DT-Sense Infared Proximity Detector : Sebagai pendeteksi mobil yang parkir, dimana dari satu modul tersebut mempunyai 2 buah modul sensor infrared yang bertindak sebagai pendeteksi atau penangkap data masukan ketika adanya mobil yang parkir.

\section{Kebutuhan Penampil dan Indikator}

a. 1 buah LCD : Sebagai layar yang menampilkan jumlah parkir yang masih tersedia serta menunjukan lokasi area tersebut.

b. 1 buah LED indikator berwarna hijau : Sebagai indikator yang menunjukan bahwa masih adanya slot parkir yang kosong.

c. 1 buah LED indikator berwarna merah : Sebagai indikator yang menunjukan bahwa slot pada area parkir tersebut telah terisi penuh.

d. 1 buah buzzer : Sebagai indikator yang mengeluarkan suara selama beberapa detik pada saat area parkir telah terisi penuh.

\section{KESIMPULAN}

Setelah dilakukan perancangan, pembuatan, pengujian dan implementasi yang dilakukan dalam penelitian ini maka dapat dikemukakan beberapa kesimpulan sebagai berikut:

Pendeteksi area parkir otomatis ini menggunakan mikrokontroler arduino uno sebagai pemroses data, sedangkan untuk mendapatkan data masukan diperoleh melalui 2 jenis sensor yang berbeda. Sensor tersebut terdiri dari sensor pembuka palang pintu otomatis dan juga sensor pendeteksi mobil yang sedang parkir, sensor palang pintu bekerja ketika sensor tersebut mendeteksi adanya mobil yang akan melintasi palang pintu yang kemudian data masukan yang diperoleh tersebut selanjutnya akan diproses lalu dikirim dalam bentuk instruksi kepada motor servo untuk membuka serta menutup palang pintu pada area parkir tersebut secara otomatis. Sedangkan untuk sensor parkir diletakan dibeberapa titik area sebagai pendeteksi apabila adanya mobil yang sedang parkir, data masukan tersebut kemudian di proses oleh arduino uno yang lalu hasil keluarannya ditampilkan pada sebuah layar LCD yang menunjukan keterangan mengenai jumlah slot parkir yang tersedia serta menunjukan dimana letak area parkir yang masih kosong. Selain menggunakan LCD sebagai alat yang memberikan keterangan, sistem ini jg dilengkapi dengan 2 buah lampu LED (hijau dan merah) yang berfungsi sebagai indikator. LED berwarna hijau yang menyala menunjukan keterangan bahwa status dari area parkir tersebut masih terdapat slot parkir yang kosong, sedangkan apabila LED berwarna merah menyala maka hal tersebut menunjukan keterangan bahwa status dari area parkir tersebut telah terisi penuh. Khusus untuk keterangan bahwa area parkir telah terisi penuh tidak hanya 
menggunakan LED berwarna merah saja, sistem ini juga dilengkapi dengan indikator lain dengan hasil keluaran berupa suara dihasilkan oleh sebuah buzzer yang akan berbunyi selama beberapa detik. Suara yang dikeluarkan oleh buzzer tersebut akan bekerja bersamaan dengan menyalanya lampu LED berwarna merah yang menujukan keterangan bahwa area parkir tersebut telah terisi penuh.

\section{DAFTAR PUSTAKA}

1. Bayu Dwi Rizkyadha Putra. 2012. "Perancangan Counter Parkir Pada Pusat Perbelanjaan Berbasis Mikrokontroler ATmega 8535". Jurusan Teknik Komputer, Tugas Akhir, Universitas Padjajaran, 2012.

2. Christoforus Yohannes. 2011. "Sistem Penghitung Jumlah Barang Otomatis Dengan Sensor Ultrasonik". Jurnal Ilmiah "Elektrikal Enjiniring" UNHAS Vol. 9, No.02, Mei - Agustus 2011.

3. Dyah Siti Istiqomah. 2013. "Prototipe Counter Kendaraan Diruang Parkir Berbasis Mikrokontroler AT89S51". Seminar Riset Unggulan Nasional Informatika dan Komputer FTI UNSA Vol. 2, No. 1, Maret 2013.

4. I Gusti Agung Putu Raka Agung dan I Made Irwan Susanto. 2012. "Rancang Bangun Prototipe Penghitung Jumlah Orang Dalam Ruangan Terpadu Berbasis Mikrokontroler ATmega328P". Jurnal Teknologi Elektro 41 Vol. 11, No. 1, Januari - Juni 2012.

5. M. Hafiz Ilham. 2007. "Perancangan Alat Penghitung Jumlah Orang Dalam Suatu Ruangan Dengan Menggunakan Sensor Infra Merah Berbasis Mikrokontroler AT89S52”. Fakultas Teknik, Tugas Akhir, Universitas Sumatera Utara. 2007.

6. McLeod Jr, Raymond. 2001. Sistem Informasi Manajemen. Edisi Ketujuh. Jakarta:PT. Prenhallindo.

7. Nasron. 2011. "Aplikasi Counter Dengan Mikrokontroler Untuk Menghitung Penonton Dipintu Masuk Stadion Dengan Sensor PING dan LED”. Jurnal Teknika Vol. XXXII, No. 1, Desember 2011. 